Marquette University

e-Publications@Marquette

College of Communication Faculty Research and

Publications

Communication, College of

6-1-2016

Exploring Organizational Communication (Micro) History Through Network Connections

Scott C. D'Urso

Marquette University, scott.durso@marquette.edu

Jeremy P. Fyke

Marquette University, jeremy.fyke@marquette.edu

David H. Torres

Marquette University

Accepted version. Review of Communication, Vol. 14, No. 2 (2014): 89-106. DOI. (C) 2014 Taylor \& Francis. Used with permission. 


\title{
Exploring Organizational Communication (Micro) History through Network Connections
}

\author{
Scott C. D'Urso \\ Marquette University \\ Milwaukee, WI \\ Jeremey P. Fyke \\ Marquette University \\ Milwaukee, WI \\ David H. Torres \\ Marquette University \\ Milwaukee, WI
}

\begin{abstract}
:
In light of the 100th anniversary of the National Communication Association, the following essay offers an initial look at the communication sub-discipline of organizational communication and its development over the past seven-plus decades. As part of this review, we advocate for the use of network methods as a microhistory analytic tool to explore the vast number of connections, both between people and research interests, generated as the discipline developed from its humble beginnings. This work represents a small sample of the greater Organizational Communication Genealogy Project. This larger effort seeks to create a detailed review of the discipline as it explores the relationships between advisors and advisees, the development of
\end{abstract}

Review of Communication, Vol. 14, No. 2 (2014): pg. 89-106. DOI. This article is (C) Taylor \& Francis (Routledge) and permission has been granted for this version to appear in e-Publications@Marquette. Taylor \& Francis (Routledge) does not grant permission for this article to be further copied/distributed or hosted elsewhere without the express permission from Taylor \& Francis (Routledge). 
dissertation and current research topics, the collaborative network of coauthorship, and the contributions of individual scholars through the analysis of interview data, narratives, and historical documents.

The field of organizational communication enjoys a rich tradition dating back to the 1940s- 50s, and its founding father W. Charles Redding. Over the past seven plus decades our interests as a field have developed to include business/industrial communication and presentational skills near the beginning to foundational understandings informed by interpretivism ${ }^{1}$. More recently, scholarship has widened the scope to view organizations as discursive constructions ${ }^{2}$, constituted by communication ${ }^{3}$, and explore the impact of various human and nonhuman actors on organizations and organizing ${ }^{4}$. Over time, various efforts have attempted to trace the contours of the field and lay out future directions ${ }^{5}$, including a 2011 special issue of Management Communication Quarterly (volume 25, issue four), and most recently in The Routledge Handbook of Language of Professional Communication $^{6}$. Right now, we write at an exciting time for organizational communication studies, on the heels of the release of The Sage Handbook of Organizational Communication ${ }^{7}$ and the 100th anniversary of the establishment of the National Communication Association (NCA). The current essay extends these earlier efforts by showcasing the first network data-driven historical analysis of the field of organizational communication.

This essay is part of a multi-year, multi-method study using network methods to map out the field of organizational communication. Tracing the field back to its origins ${ }^{8}$, two of the most influential publications that employed the precise phrasing "organizational communication" were in fact network studies. Thus, our approach is a fitting way to reflect back on the field. This method allows us to visually represent the discipline, and thus discuss trends and relationships in nuanced ways. Network methods have been used to study disciplines as they offer a way to explore diverse things such as citation patterns, journal selection, topics, editor decisions, and collaborations and thought leaders ${ }^{9}$. The larger Organizational Communication Genealogy Project (OCGP) affords a look into the development of ideas and research areas, as well as the growth and diversity of scholars in the field. In any field, people and projects are key influences as we determine our interests and niche ${ }^{10}$; our effort

Review of Communication, Vol. 14, No. 2 (2014): pg. 89-106. DOI. This article is (C) Taylor \& Francis (Routledge) and permission has been granted for this version to appear in e-Publications@Marquette. Taylor \& Francis (Routledge) does not grant permission for this article to be further copied/distributed or hosted elsewhere without the express permission from Taylor \& Francis (Routledge). 
provides a unique and first look at these influences. In line with these broad aims, the current essay offers a slice of the larger picture gleaned from our ongoing project as part of NCA's 100th anniversary celebration. Specifically, we track the field through the advisor-advisee dyad, dissertation and ongoing research topics, and key scholars in the field.

Our primary goal is to orient the field to the potential of the data by providing the rationale for and benefits of utilizing network methods to explore our field, and to highlight a portion of the discipline's microhistory. To accomplish this, we first describe the network approach and methods that ground our overall project. Then, we present exemplars of this research, including network images and descriptions for each of the areas listed above. In each of the exemplar sections, we end with a series of data-driven questions to reflect on our preliminary findings and future analysis. These questions lay the groundwork and help articulate a research agenda for scholars generally and our genealogy project specifically. We conclude by detailing the implications of the current essay and larger genealogy project by posing overarching, macro- level questions that future analyses will explore.

\section{Networks as Analytic Tool}

Network methods have been used for some time to enrich our understandings of various sociocultural processes. Although scholars have been interested in networks for more than two centuries, studies increased in areas of communication and organizations at the turn of the last century ${ }^{11}$. The study of organizations from a network perspective owes much to the tradition established at Michigan State University where scholars investigated topics such as communication channels and small group decision making ${ }^{12}$.

Beyond understanding specific topics and processes, network methods also afford a comprehensive macro-level assessment of a discipline. One of the largest such projects is The Mathematics Genealogy Project (http://genealogy.math.ndsu.nodak.edu/index.php), hosted by North Dakota State University, which explores that discipline's history through the connections of its scholars over time. Their database, 
established in 1997, includes more than 181,000 records spanning centuries, and includes data on advisors, academic descendants, and dissertation topics. In many ways, we attempted to model our project after this effort. Additionally, scholars have used networks to explore the history of English ${ }^{13}$, international relations ${ }^{14}$, Marketing ${ }^{15}$, and management and organization studies ${ }^{16}$. In line with the current study's aims, research demonstrates that networks can be used to discover a field's "peculiarities" in terms of why authors collaborate, lineages between authors, and how collaboration affects and is affected by journal outlet selection. ${ }^{17}$ Furthermore, network methods focusing on keywords and authors can be used to assess the coherence or dividedness of a discipline in terms of methods and topics of study ${ }^{18}$.

For our project, we examine both global and individual network characteristics present in the discipline. For this manuscript, we highlight a few of these characteristics (see Table 1) when examining the collaborative network exemplar. For the overall project, these tools will allow us to identify key individuals responsible for the growth of our field in terms of advising new Ph.D.S, as well as those individuals who are prominent in the collaborative publication efforts in the discipline.

Insert Table 1 Approximately Here ${ }^{19}$

\section{Methods}

The data for the OCGP project has been and will be gathered in many ways. Initially, we were relying on a survey questionnaire (http://www.marquette.edu/genealogy-form/), which allowed participants to directly submit data. Currently, we are collecting CVs of scholars not in the database, both living and deceased. Additionally, we are collecting qualitative data in the forms of narratives, interviews, and focus groups with prominent scholars in the discipline. Future data collection will involve site visits to several key institutions to examine archival data. One such example (see Figure 1) is an early CV from Fredric M. Jablin when he was an assistant professor at the University of Texas. Additionally, we have acquired archival data, in the form of records from the International Communication 
Association's (ICA) Organizational Communication Division, mid-1960s newsletters from the former Business and Professional Speaking Interest Group that was a part of what has become NCA, as well as access to a significant portion of W. Charles Redding's personal files from Purdue University.

Insert Figure 1 Approximately Here

To date 127 participants have provided data, primarily through the genealogy survey, but some by sending a copy of their CV. Recruitment for this project unfolded in several steps. Recruitment not only served pragmatic, data collection purposes, but also allowed us to draw at least a preliminary boundary for our study. Invitations were sent out through ICA and NCA email listservs to individuals affiliated with the organizational communication division. These two listservs alone allowed us to reach 1700 individuals. Our project was also announced at the NCA conference, at the Organizational Communication Mini-Conference (OCMC) in 2012, and at ICA in 2013, with preliminary results presented at OCMC 2013. Boundary management for our project was challenging given the interdisciplinarity of communication and organizational communication specifically, but these listservs and conference affiliations gave us a starting point. With a participation rate of less than $8 \%$ of the population, we are taking a more proactive approach to collecting genealogical data by gathering CVs from ICA and NCA Organizational Communication members. Additionally, we are sending out personal invitations for narratives and interviews with influential scholars.

Despite the low participation rate, survey data collection resulted in 392 genealogy network participants and 299 collaboration network participants. To examine this preliminary data, we analyzed the genealogical data relevant to the advisor-advisee relationship. The data was examined utilizing UCINET ${ }^{20}$ and NetDraw ${ }^{21}$ to visualize participant connections. Additionally, top dissertation and current research interest keywords were also assessed. Finally, UCINET and NetDraw were used to both visualize the network, and to also assess key individual network characteristics relevant to the study of coauthorship in the discipline.

Review of Communication, Vol. 14, No. 2 (2014): pg. 89-106. DOI. This article is (C) Taylor \& Francis (Routledge) and permission has been granted for this version to appear in e-Publications@Marquette. Taylor \& Francis (Routledge) does not grant permission for this article to be further copied/distributed or hosted elsewhere without the express permission from Taylor \& Francis (Routledge). 
Given what network analysis can accomplish, this methodology aligns well with our goals in this project. As Miller aptly describes "[t]he path taken by the field of organizational communication gets more complex every day with lots of side paths and meandering"22. What follows is a visual rendering of such meandering, followed by our interpretations and pressing questions that will guide the future of the project.

\section{Genealogy Project Exemplars}

\section{Genealogical Lines}

As this project began with an idea to trace the genealogical history of the discipline of organizational communication, this is where the bulk of the initial work has gone. Knowing one's place in history can be an enlightening endeavor. With 127 participants in the database thus far, who in turn are connected to nearly 250 more scholars, we have begun piecing together our genealogical past. What does this look like? Figure 2 provides a glimpse into one small portion of this history through four generations of organizational communication scholars. It begins with Ernest Bormann, the late rhetorician and prominent communication scholar from the University of Minnesota. While not an organizational communication scholar, his interest in rhetorical analysis and aspects of group communication hint at some of the research his academic descendants would thrive upon. Arguably one of his most successful students and scholars, Linda L. Putnam, currently the chair of the Department of Communication at the University of California, Santa Barbara, has gone on to make immeasurable contributions to the field, both in terms of knowledge (over 140 publications to date), but in service (former International Communication Association (ICA) president) and teaching as well (numerous awards and recognitions). She was recognized for these contributions with the 1993 ICA Fredric M. Jablin Award. Beyond these contributions, impact can be assessed through fecundity-the number of protégés a mentor trains ${ }^{23}$. Putnam has been the chair or co-chair to 16 students who went on to earn their Ph.D.'s in the field. While this would be significant enough, several of Putnam's former advisees have also made their mark on our discipline at top tier programs such as the Université de Montréal, University of Colorado Boulder, DePaul University, and Arizona State University.

Review of Communication, Vol. 14, No. 2 (2014): pg. 89-106. DOI. This article is (C) Taylor \& Francis (Routledge) and permission has been granted for this version to appear in e-Publications@Marquette. Taylor \& Francis (Routledge) does not grant permission for this article to be further copied/distributed or hosted elsewhere without the express permission from Taylor \& Francis (Routledge). 
One of the most prominent and prolific former Putnam students is Patrice Buzzanell (Purdue University), the 1988 W. Charles Redding Dissertation of the Year winner and 1994 Fredric M. Jablin Award winner. She is a productive and distinguished scholar (over 125 publications, numerous awards, and also a former president of ICA), who has also maintained a high degree of fecundity, chairing or cochairing 25 doctoral dissertations in organizational communication. Several of her former students are successful scholars and teachers at many prominent educational institutions such as Marquette University, Purdue University, and the University of Texas at Austin.

Continuing down the genealogical line, Rebecca Meisenbach (University of Missouri) has made significant contributions to the field (25 publications) and is taking on an active role in the education of future organizational communication scholars. Meisenbach's first Ph.D. student, Disraelly Cruz, is currently at the University of West Florida. She was recently joined by Amanda Medlock-Klyukovski, Candy Noltensmeyer, and Marlo Goldstein-Hode in 2014. They represent the current, but likely temporary, end to the Bormann/Putnam lineage (47 scholars to date) in the field of organizational communication. Two more of Meisenbach's Ph.D. students will be completing their degrees over the next few years. Since 1976, over 290 publications in organizational communication can be traced to this one small portion of the overall genealogy of the field (i.e., Putnam, Buzzanell, Meisenbach). Other lineages, such as those from W. Charles Redding, whose descendants include Phillip Tompkins, Frederic Jablin, Gerald Goldhaber, George Cheney, Michael Kramer, Patricia Sias, Kathy Krone, Connie Bullis, and Greg Larson, can highlight the development of the discipline through the individuals and relationships from a perspective not yet captured. Understanding such genealogical lines and linkages is important because one's distinctive position in a network affords benefits in terms of productivity, production patterns, and diffusion of knowledge 24,25 .

A prime example of this type of research utilized data from the previously mentioned Mathematics Genealogy Project. The mentorprotégé relationship was examined over a period of 60 years, focusing 
on whether or not advisees mimic career choices, productivity, and fecundity. Key findings included a stable average fecundity over time, and generally higher rates of fecundity among advisees with advisors with high mentorship fecundity. Similar analysis will be conducted with the OCGP dataset. The exemplar above appears to anecdotally support this notion of higher advisee output. Future OCGP work will seek to answer the following research questions related to genealogical lines:

$\mathrm{RQ}_{1}$ : How does an advisee's network affect that person's ability to obtain certain resources (e.g., collaborations, the advisor's knowledge network)?

$\mathrm{RQ}_{2}$ : How does an advisor's fecundity affect/influence an advisee's fecundity?

$\mathrm{RQ}_{3}$ : How does an advisor's research output affect/influence the advisee's productivity?

$\mathrm{RQ}_{4}$ : What benefits do advisees reap as a result of their advisor's fecundity?

\section{Research and Dissertation Topics}

Beyond this knowledge of where we come from, the genealogy project also seeks to understand the development of the field topically through the various lineages. Table 2 examines this process utilizing the Bormann/Putnam lineage from above. From a keyword perspective, we can see how dissertation research has evolved over the past several decades. From Bormann's 1953 rhetorical analysisfocused research to Cruz's work on volunteering, work-life balance and enrichment in 2009, each succeeding generation builds upon and sometimes expands the work of the previous generation. This can also been seen by examining keywords from each of the scholars general research interests of their career.

Insert Table 2 Approximately Here

At the discipline level, looking at keywords from dissertations and general research interests can be helpful in examining how the field has grown and diversified, but also in discovering that there are key issues that are at the heart of our discipline. Table 3 presents a

Review of Communication, Vol. 14, No. 2 (2014): pg. 89-106. DOI. This article is (C) Taylor \& Francis (Routledge) and permission has been granted for this version to appear in e-Publications@Marquette. Taylor \& Francis (Routledge) does not grant permission for this article to be further copied/distributed or hosted elsewhere without the express permission from Taylor \& Francis (Routledge). 
look at the most frequently used dissertation keywords among the 127 project participants. Dissertations dates range from 1960 to 2013 ( $M=$ 1999). Participants submitted 573 unique keywords describing their dissertation research. Keywords that were mentioned 5 or more times by various scholars accounted for a little more than $17 \%$ of all dissertation keywords. The most frequent keyword, "Organizational Communication", was mentioned only 15 times, or $11.81 \%$ of all of our participants, but only $2.61 \%$ of all of the dissertation keywords submitted. As our database grows, it will be revealing to see how this list changes, particularly as we obtain historical data on dissertations dating back to the 1950s, 1960s, and 1970s.

Insert Table 3 Approximately Here

Previous studies have shown that network methods can be a valuable way to map the complexity of research and identify knowledge gaps in extant research paradigms ${ }^{26}$. Accordingly, looking at the most frequently identified research keywords, this list gives a detailed look at what is currently going on in the field of organizational communication. Again, participants provided an enormous variety of keywords to describe their research $(n=570)$. Here topics that were reported five or more times (see Table 4 ) accounted for just over a quarter of all keywords submitted (25.79\%). Again, "Organizational Communication" was the most frequently used term, being reported 20 times, or by $15.75 \%$ of the respondents.

With the vast number of topics reported, future analysis will employ NVivo qualitative analysis software to look more deeply into the development of research ideas over time, the current state of interdisciplinary work, and the cohesiveness of research within the discipline ${ }^{27}$. This analysis will allow us to answer the following research topic-related questions:

$\mathrm{RQ}_{5}$ : What is the identity of organizational communication topically?

$\mathrm{RQ}_{6}$ : How does lineage influence research and dissertation topic selection?

$\mathrm{RQ}_{7}$ : How does lineage affect the development/advancement of research topics in the field? 
$\mathrm{RQ}_{8}$ : From a topical perspective, what are various interdisciplinary possibilities that have yet to be explored?

Insert Table 4 Approximately Here

\section{Collaboration/Co-authorship}

As part of the OCGP, we are also investigating the collaborative nature of our discipline through the examination of co-authorship. Our investigation of co-authorship is of consequence for a number of reasons. Previous studies have demonstrated that coauthoring improves the quality of submissions ${ }^{28}$, and increases the probability of acceptance. Furthermore, acceptance and allocation of editorial space is influenced by the affiliations among authors, editors, and coeditors, which begins in graduate school and continues in current employment ${ }^{29}, 30,31$. Analyzing the preliminary data we have put together an initial network map of collaboration. For each scholar, we initially recorded up to five ${ }^{32}$ scholars with whom each had co-authored most frequently. Figures 3-5 show an n-clique exemplar of this data at its most basic level where $n=3$. This limit was chosen because an $n-$ clique greater than three is not very meaningful ${ }^{33}$. Starting with Stan Deetz (University of Colorado-Boulder), there are seven first-degree connections. Within this first degree network, we find the first clique (Deetz-Egar-Tracy). From this relatively small number, when we can extend the collaboration network one degree further, an additional 20 scholars join the network. This expansion reveals five additional network cliques. Pushing the network out one more degree reveals 52 additional network connections and an additional six network cliques. Overall, 80 scholars are represented in this collaboration exemplar with no one more than three degrees of separation away from Deetz. This example represents nearly $20 \%$ of all of scholars currently in our preliminary data set. Understanding these smaller subgroups as well as the overall collaboration network can help us understand some aspects of our discipline and the impacts of co-authorship, as noted earlier (e.g., access to prominent journals, quality of submissions, probability of acceptance).

Insert Figures 3 through 5 Approximately Here

Review of Communication, Vol. 14, No. 2 (2014): pg. 89-106. DOI. This article is (C) Taylor \& Francis (Routledge) and permission has been granted for this version to appear in e-Publications@Marquette. Taylor \& Francis (Routledge) does not grant permission for this article to be further copied/distributed or hosted elsewhere without the express permission from Taylor \& Francis (Routledge). 
Beyond this basic examination of the exemplar collaboration network, an analysis of actors reveals even more about the individual scholars and their place in this network. Table 5 examines both network centrality and betweenness for individuals within 2 degrees of Deetz. Although the exemplar begins with Deetz in the center, seven individuals have higher centrality scores relative to Deetz. Similarly, there are six individuals with higher betweenness scores. In both cases, Putnam has a higher degree of centrality and betweenness for the entire sample network. The sample network itself has a relatively low density $(3.32 \%)$ indicating a significant degree of diverse collaborative connections. Examining measures such as those reported here is consequential as it points to the role that certain prominent individuals have in connecting relatively isolated parts of a network ${ }^{34}$. With the future addition of all co-authors to the collaboration data, the network characteristics such as betweenness and centrality, and overall network size and density, will help make further sense of collaboration impact. With future analyses we seek to answer the following questions related to collaboration and co-authorship: $\mathrm{RQ}_{9}:$ How does one's collaboration network affect research
acceptance?

$\mathrm{RQ}_{10}$ : Does one's collaboration network affect access to prominent journals in the field?

$\mathrm{RQ}_{11}$ : Is there a relationship between collaboration and prominence in the field?

Insert Table 5 Approximately Here

\section{Conclusion and Implications}

The preceding highlights what is possible through a network analysis of organizational communication. First, the genealogy demonstrates rich history and tracks the movement of, and connections between, prominent scholars and their advisees. In the early stages of the development of the field (early 1980s), up-andcoming researchers learned much through personal connections and forming relationships, not simply through reading published research 
(M. Kramer, personal communication). Thus, a genealogical perspective is apt given the close ties among members of the field. Second, we will trace how dissertation and ongoing research topics are evolving. In a simple yet profound way, we will be able to depict the essence of our discipline through key terms. With the above in mind, we offer the following implications.

First, our project gives insight into the topics and research areas comprising our field. One implication of considering topics relates to the interdisciplinarity of the overall communication field. We feel that our findings are of interest to anyone outside of organizational communication, and can provide a way for scholars outside the subfield to understand the essence of our discipline topically, and who the prominent authors are and their collaboration patterns, thereby making it easier to seek new ties and research avenues. Put simply, we can open up new ways of collaborating and finding one's place in a different field that is interdisciplinary at its core. This openness can affect established scholars in other fields, but also, for instance, students looking to find their places in graduate studies. A network understanding of our field topically can be used as a teaching tool to discuss established and current hot topics, and also highlight topics that have remained dormant for some time. Another potential utility of these data is by looking at the types of questions we seek to answer with our scholarship. Although we all have our own niche, topical foci, and lenses through which we conduct our research, as a practical discipline ${ }^{35}$ we should reflect, for instance, on broad calls for scholarship that address large-scale impacts of communication research. Such impact aligns with concerns of other scholars ${ }^{36}$ who have reviewed our history as a field and challenge us to consider carefully the utility of our research to people in actual organizations. To add a further example, our keyword results reveal that "organization" was low on the commonly-cited list. This finding is interesting given efforts to question and engage what constitutes "organization" in the 21 st century ${ }^{37}$.

Second, this effort contributes to other projects that offer histories of their field. As W. Charles Redding ${ }^{38}$ and more recent reviews ${ }^{39}$ remind us, such disciplinary reflections are important as fields seek to understand their identities vis-à-vis the society in which they operate. To the already excellent histories available, we offer a

Review of Communication, Vol. 14, No. 2 (2014): pg. 89-106. DOI. This article is @ Taylor \& Francis (Routledge) and permission has been granted for this version to appear in e-Publications@Marquette. Taylor \& Francis (Routledge) does not grant permission for this article to be further copied/distributed or hosted elsewhere without the express permission from Taylor \& Francis (Routledge). 
network-based genealogical history. Importantly, we will be able to provide recognition to key scholars (both well-known and otherwise) and their contributions to our discipline. Third, it gives us nuanced ways of examining influence, both in terms of people and research areas.

Having provided the preceding implications, we close by noting overarching research questions to guide future inquiry. First, what do the combined networks (i.e., genealogy and collaboration) tell us about the discipline? Using Quadratic Assignment Procedure (QAP) will allow us to analyze the multiplex of overlapping collaborator, advisor, and topic networks ${ }^{40}$ to add nuance to our understanding of scholarly productivity and the overall development of the discipline. Second, and related, what are some of the most influential collaborations, and, practically speaking, are there certain factors that influence the success of collaboration connections? Finally, how does the analysis of our discipline relate to findings from other fields such as the ones mentioned in this essay (e.g., mathematics, international relations, marketing)? Such comparisons can be helpful as they allow us to learn lessons from established fields, and measure the advancement of our discipline.

This essay joins in the scholarly conversation that traces the field of organizational communication at an important time in the history of the overall field of communication. Our aim is to contribute to a healthy body of research that captures the growth of our field since its inception in the 1940s-1950s. By approaching history via network methods, we offer scholars and students a picture that is unseen thus far. As the larger Organizational Communication Genealogy Project continues to evolve and take shape, we look forward to offering further insight to this fully established and vibrant field.

FIGURE 1 EARLY CURRICULUM VITAE FOR FREDRIC M. JABLIN

Review of Communication, Vol. 14, No. 2 (2014): pg. 89-106. DOI. This article is (C) Taylor \& Francis (Routledge) and permission has been granted for this version to appear in e-Publications@Marquette. Taylor \& Francis (Routledge) does not grant permission for this article to be further copied/distributed or hosted elsewhere without the express permission from Taylor \& Francis (Routledge). 
NOT THE PUBLISHED VERSION; this is the author's final, peer-reviewed manuscript. The published version may be accessed by following the link in the citation at the bottom of the page.

VITA

Fredric M. Jablin

\section{HOME ADDRESS}

3215 Harpers Ferry Iane

Austin, Texas 78745

Telephone: (512) 282-2517

\author{
PERSONAL \\ Date of Birth: July 23, 1952 \\ Marital Status: Single \\ Health: Excellent

\section{EDUCATION} \\ SUNY at Buffalo \\ Buffalo, New York \\ University of Michigan \\ Ann Arbor, Michigan \\ Purdue University \\ West Lafayette, Indiana

\section{TEACHING EXPERTENCE}

Graduate Teaching Fellow (1973-74)

University of Michigan (UM)

Graduate Teaching Assistant (1974-77)

Purdue University (PU)

Assistant Professor (1977-79)

Internship Director

University of Wisconsin-Milwaukee

(UWM)

\section{UNIVERSITY ADDRESS}

Department of Speech Communication

University of Texas at Austin Austin, Texas 78712

Telephone: (512) 471-5251

\author{
B.A. 1973 \\ Major: Speech Communication and \\ Political Science \\ M.A. 1974 \\ Major: Interpersonal and Organiza- \\ tional Communication \\ Ph.D. 1977 \\ Major: Organizational and Inter- \\ personal Conmunication \\ COURSES TAUGHT \\ Fundamentals of Public Speaking \\ Fundamentals of Speech Comminication \\ Interviewing: Principles and Practices \\ Interviewers and Interviewing \\ Conmunication in Organizations \\ Organizational Communication Analysis \\ Internship in Communication \\ Studies of Communication in Organiza- \\ tions: Contingency Theory (Graduate) \\ Studies of Communication in Organiza- \\ tions: Socialization Processes \\ (Graduate)
}

\section{NOTE: - Courtesy of The University of Texas at Austin, Moody College of Communication.}

Review of Communication, Vol. 14, No. 2 (2014): pg. 89-106. DOI. This article is (C) Taylor \& Francis (Routledge) and permission has been granted for this version to appear in e-Publications@Marquette. Taylor \& Francis (Routledge) does not grant permission for this article to be further copied/distributed or hosted elsewhere without the express permission from Taylor \& Francis (Routledge). 
NOT THE PUBLISHED VERSION; this is the author's final, peer-reviewed manuscript. The published version may be accessed by following the link in the citation at the bottom of the page.

\section{FIGURE 2 GENEALOGY NETWORK DIAGRAM EXEMPLAR}

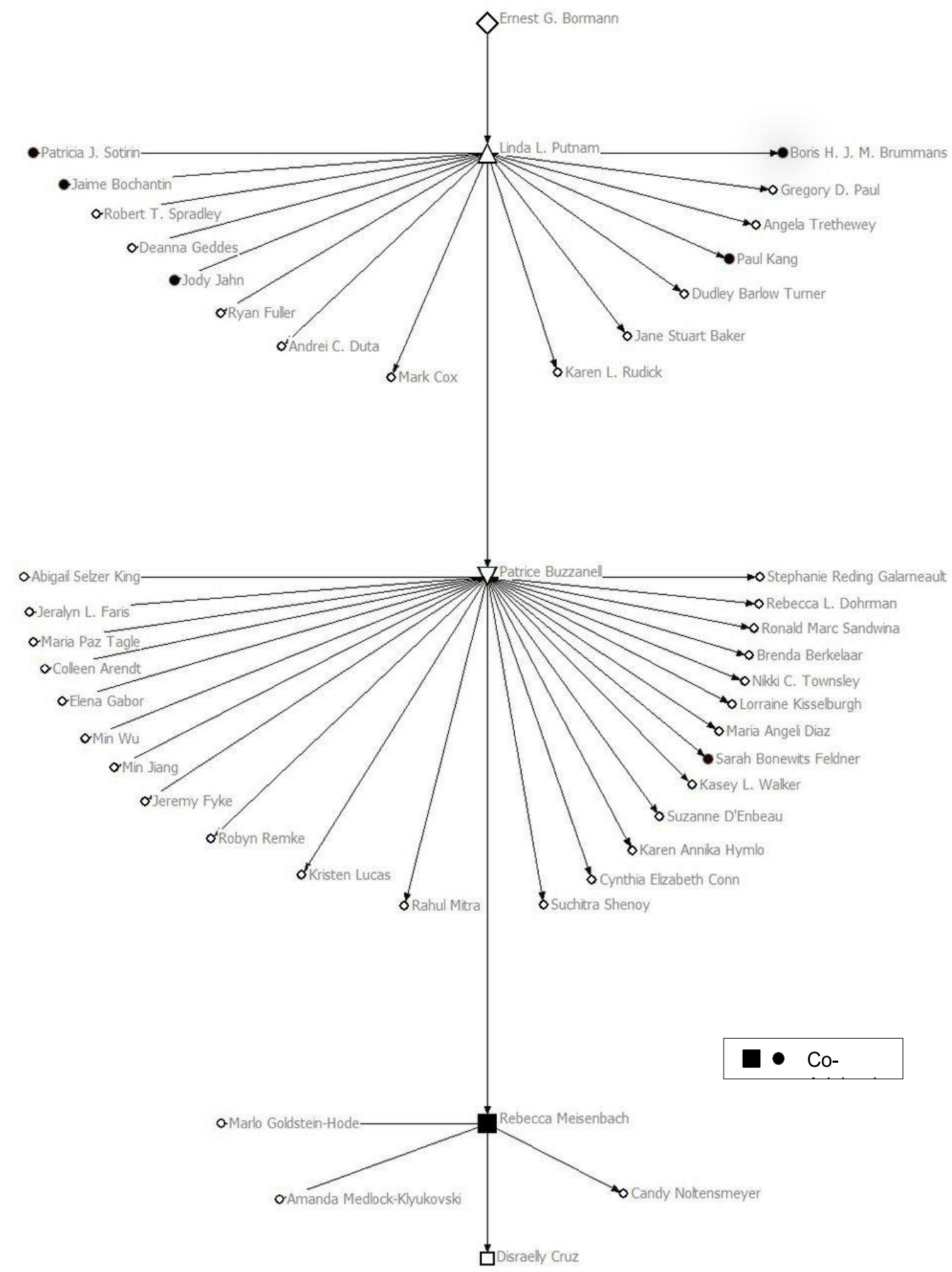

Review of Communication, Vol. 14, No. 2 (2014): pg. 89-106. DOI. This article is (C) Taylor \& Francis (Routledge) and permission has been granted for this version to appear in e-Publications@Marquette. Taylor \& Francis (Routledge) does not grant permission for this article to be further copied/distributed or hosted elsewhere without the express permission from Taylor \& Francis (Routledge). 
NOT THE PUBLISHED VERSION; this is the author's final, peer-reviewed manuscript. The published version may be accessed by following the link in the citation at the bottom of the page.

FIGURE 3 RESEARCH COLLABORATION NETWORK EXEMPLAR - STAN DEETZ (NCLIQUE, $\mathrm{N}=1$ )

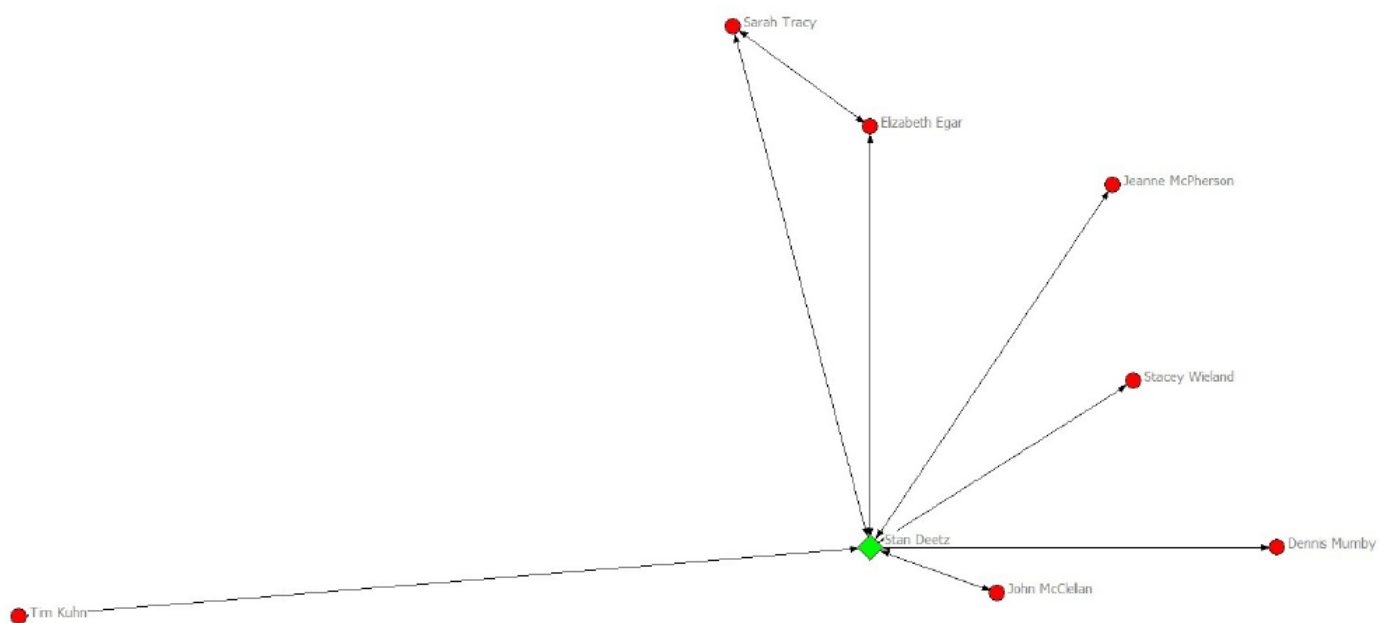

FIGURE 4 RESEARCH COLLABORATION NETWORK EXEMPLAR - STAN DEETZ (NCLIQUE, $N=2$ )



Review of Communication, Vol. 14, No. 2 (2014): pg. 89-106. DOI. This article is (C) Taylor \& Francis (Routledge) and permission has been granted for this version to appear in e-Publications@ Marquette. Taylor \& Francis (Routledge) does not grant permission for this article to be further copied/distributed or hosted elsewhere without the express permission from Taylor \& Francis (Routledge) 
NOT THE PUBLISHED VERSION; this is the author's final, peer-reviewed manuscript. The published version may be accessed by following the link in the citation at the bottom of the page.

FIGURE 5 RESEARCH COLLABORATION NETWORK EXEMPLAR - STAN DEETZ (NCLIQUE, $N=3$ )

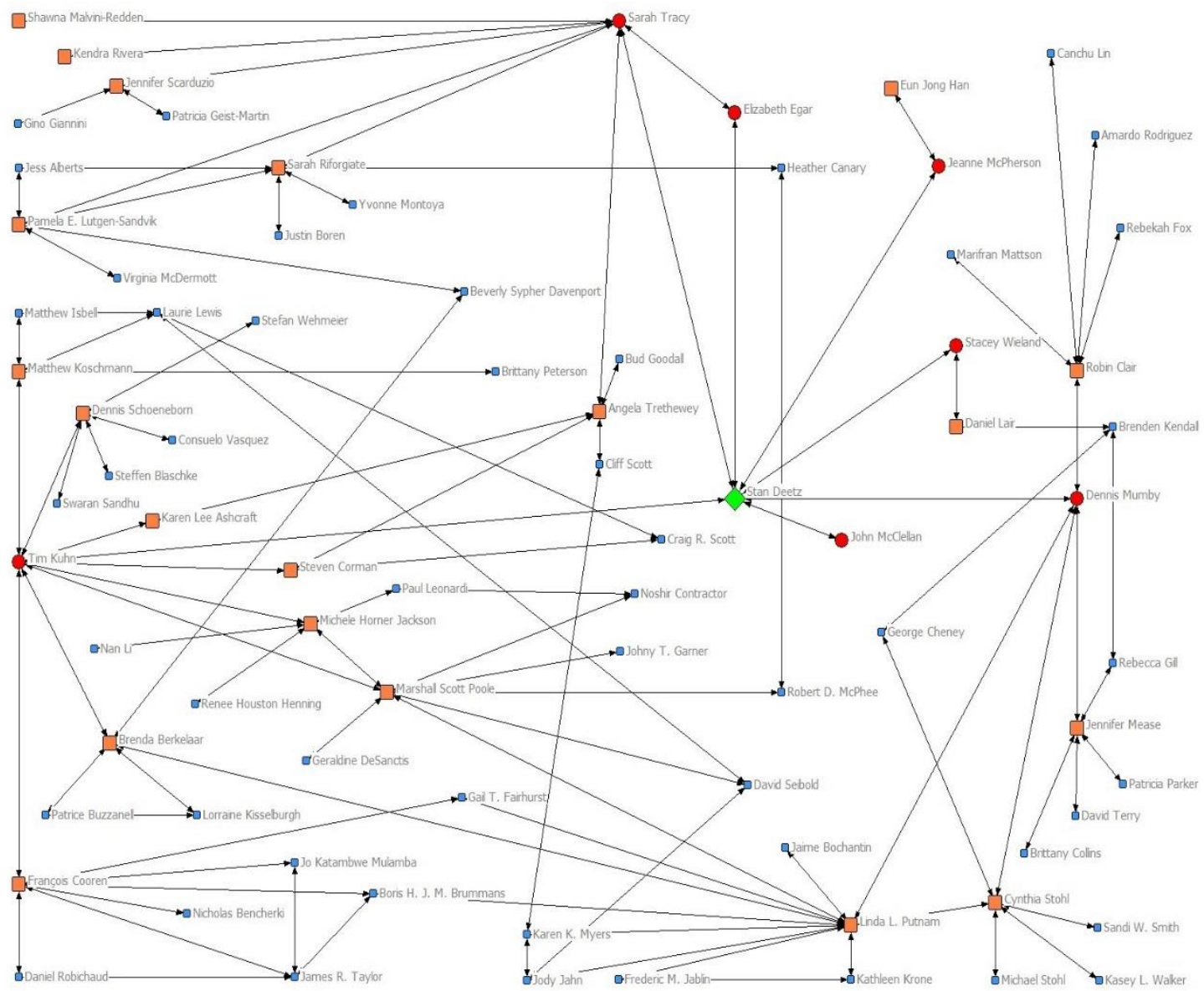

Review of Communication, Vol. 14, No. 2 (2014): pg. 89-106. DOI. This article is (C) Taylor \& Francis (Routledge) and permission has been granted for this version to appear in e-Publications@Marquette. Taylor \& Francis (Routledge) does not grant permission for this article to be further copied/distributed or hosted elsewhere without the express permission from Taylor \& Francis (Routledge). 
NOT THE PUBLISHED VERSION; this is the author's final, peer-reviewed manuscript. The published version may be accessed by following the link in the citation at the bottom of the page.

TABLE 1 KEY NETWORK ANALYSIS MEASURES AND TERMS ${ }^{19}$

\begin{tabular}{ll}
\hline \multicolumn{1}{c}{ Measure } & \multicolumn{1}{c}{ Definition } \\
\hline Degree & Number of direct links with other actors. \\
$\begin{array}{l}\text { Bonacich's } \\
\begin{array}{l}\text { Power } \\
\text { Centrality }\end{array}\end{array}$ & $\begin{array}{l}\text { A centrality measure that is a function of how many connections an actor has } \\
\text { within the network, while also considering the degree of the nodes to which } \\
\text { the actor is connected. This measure is often equated with network power. }\end{array}$ \\
$\begin{array}{l}\text { Betweenness } \\
\text { Centrality }\end{array}$ & $\begin{array}{l}\text { A centrality measure that looks at the extent to which an actor mediates or } \\
\text { falls between any other two actors on the shortest path between those actors. }\end{array}$ \\
Usually averaged across all possible pairs in the network. \\
Density & $\begin{array}{l}\text { The density of the network is "the proportion of all possible ties that are } \\
\text { actually present". This is typically reported as a percentage. }\end{array}$ \\
Distance & $\begin{array}{l}\text { Distance is another useful measurement when quantifying a network as a } \\
\text { whole. Distance is often, quite simply, referred to as "the number of links } \\
\text { between two nodes" or path length. }\end{array}$ \\
Cliques & $\begin{array}{l}\text { Cliques represent a sub-network in which "individuals in the network are all } \\
\text { directly connected to one another, but are not all directly connected to any } \\
\text { additional individuals in the network." }\end{array}$ \\
N-Cliques & $\begin{array}{l}\text { A clique in which every pair of individuals is connected by a path of length } n \\
\text { or less. }\end{array}$ \\
\hline
\end{tabular}

Review of Communication, Vol. 14, No. 2 (2014): pg. 89-106. DOI. This article is (C) Taylor \& Francis (Routledge) and permission has been granted for this version to appear in e-Publications@Marquette. Taylor \& Francis (Routledge) does not grant permission for this article to be further copied/distributed or hosted elsewhere without the express permission from Taylor \& Francis (Routledge). 
NOT THE PUBLISHED VERSION; this is the author's final, peer-reviewed manuscript. The published version may be accessed by following the link in the citation at the bottom of the page.

TABLE 2 EXEMPLAR OF KEYWORD HISTORY THROUGH PH.D. ADVISOR-ADVISEE GENEALOGY

\begin{tabular}{|c|c|c|}
\hline SCHOLAR & DISSERTATION & RESEARCH \\
\hline $\begin{array}{l}\text { Ernest G. Bormann } \\
\text { Ph.D., } 1953 \\
\text { University of Iowa }\end{array}$ & $\begin{array}{l}\text { 1. Rhetorical Analysis } \\
\text { 2. National Radio Broadcast } \\
\text { 3. Speeches } \\
\text { 4. Senator Huey Long }\end{array}$ & $\begin{array}{l}\text { 1. Rhetorical Analysis } \\
\text { 2. Symbolic Interaction } \\
\text { 3. Group Communication } \\
\text { 4. Organizational Sagas } \\
\text { 5. Rhetorical Fantasies }\end{array}$ \\
\hline $\begin{array}{l}\text { Linda L. Putnam } \\
\text { Ph.D., } 1977 \\
\text { University of Minnesota }\end{array}$ & $\begin{array}{l}\text { 1. Psychometrics } \\
\text { 2. Task Groups } \\
\text { 3. Procedures } \\
\text { 4. Agendas } \\
\text { 5. Organization }\end{array}$ & $\begin{array}{l}\text { 1. Conflict } \\
\text { 2. Negotiation } \\
\text { 3. Discourse } \\
\text { 4. Gender } \\
\text { 5. Groups }\end{array}$ \\
\hline $\begin{array}{l}\text { Patrice Buzzanell } \\
\text { Ph.D., 1987 } \\
\text { Purdue University }\end{array}$ & $\begin{array}{l}\text { 1. Career } \\
\text { 2. Sensemaking } \\
\text { 3. Structure } \\
\text { 4. Information } \\
\text { 5. Engineering }\end{array}$ & $\begin{array}{l}\text { 1. Careers } \\
\text { 2. Social Change } \\
\text { 3. Gender } \\
\text { 4. Leadership } \\
\text { 5. Ethics }\end{array}$ \\
\hline $\begin{array}{l}\text { Rebecca Meisenbach } \\
\text { Ph.D., } 2004 \\
\text { Purdue Univeristy }\end{array}$ & $\begin{array}{l}\text { 1. Organizational Identity } \\
\text { 2. Fundraisers } \\
\text { 3. Nonprofit(s) } \\
\text { 4. Stigma }\end{array}$ & $\begin{array}{l}\text { 1. Identity } \\
\text { 2. Gender } \\
\text { 3. Nonprofit Organization } \\
\text { 4. Ethics } \\
\text { 5. Stigma }\end{array}$ \\
\hline $\begin{array}{l}\text { Disraelly Cruz } \\
\text { Ph.D., } 2009 \\
\text { University of Missouri }\end{array}$ & $\begin{array}{l}\text { 1. Volunteering } \\
\text { 2. Work-Life Balance } \\
\text { 3. Work-Life Enrichment } \\
\text { 4. Identity } \\
\text { 5. Role Management }\end{array}$ & $\begin{array}{l}\text { 1. Work-Life Balance } \\
\text { 2. Identity } \\
\text { 3. Nonprofit Sustainability } \\
\text { 4. Volunteering } \\
\text { 5. Role Management }\end{array}$ \\
\hline
\end{tabular}

Review of Communication, Vol. 14, No. 2 (2014): pg. 89-106. DOI. This article is (C) Taylor \& Francis (Routledge) and permission has been granted for this version to appear in e-Publications@Marquette. Taylor \& Francis (Routledge) does not grant permission for this article to be further copied/distributed or hosted elsewhere without the express permission from Taylor \& Francis (Routledge). 
NOT THE PUBLISHED VERSION; this is the author's final, peer-reviewed manuscript. The published version may be accessed by following the link in the citation at the bottom of the page.

TABLE 3 MOST FREQUENTLY USED DISSERTATION KEYWORDS

\begin{tabular}{lccc}
\hline \multicolumn{1}{c}{ KEYWORD } & Frequency & $\begin{array}{c}\text { KEYwORD } \\
\text { PERCENTAGE }\end{array}$ & $\begin{array}{c}\text { ScholAR } \\
\text { PERCENTAGE }\end{array}$ \\
\hline Organizational Communication & 15 & 2.61 & 11.81 \\
Identity & 11 & 1.91 & 8.66 \\
Communication & 11 & 1.91 & 8.66 \\
Power & 11 & 1.91 & 8.66 \\
Change & 7 & 1.22 & 5.51 \\
Organization & 6 & 1.05 & 4.72 \\
Technology & 6 & 1.05 & 4.72 \\
Culture(s) & 6 & 1.05 & 4.72 \\
Networks & 5 & 0.87 & 3.94 \\
Sensemaking & 5 & 0.87 & 3.94 \\
Discourse & 5 & 0.87 & 3.94 \\
Leadership & 5 & 0.87 & 3.94 \\
Structuration & 5 & 0.87 & 3.94 \\
\hline
\end{tabular}

NOTE. - List represents $17.10 \%$ of all dissertation keywords $(\mathrm{N}=573)$ used

Review of Communication, Vol. 14, No. 2 (2014): pg. 89-106. DOI. This article is (C) Taylor \& Francis (Routledge) and permission has been granted for this version to appear in e-Publications@Marquette. Taylor \& Francis (Routledge) does not grant permission for this article to be further copied/distributed or hosted elsewhere without the express permission from Taylor \& Francis (Routledge). 
NOT THE PUBLISHED VERSION; this is the author's final, peer-reviewed manuscript. The published version may be accessed by following the link in the citation at the bottom of the page.

\section{TABLE 4 MOST FREQUENTLY USED RESEARCH KEYWORDS}

\begin{tabular}{lccc}
\hline \multicolumn{1}{c}{ KEYwORD } & FREQUENCY & $\begin{array}{c}\text { KEYwORD } \\
\text { PERCENTAGE }\end{array}$ & $\begin{array}{c}\text { ScholaR } \\
\text { PERCENTAGE }\end{array}$ \\
\hline Organizational Communication & 20 & 3.51 & 15.75 \\
Identity & 13 & 2.28 & 10.24 \\
Power & 11 & 1.93 & 8.66 \\
Leadership & 10 & 1.75 & 7.87 \\
Change & 8 & 1.40 & 6.30 \\
Collaboration & 8 & 1.40 & 6.30 \\
Organizational Change & 7 & 1.23 & 5.51 \\
Communication & 6 & 1.05 & 4.72 \\
Gender & 6 & 1.05 & 4.72 \\
Organizational Culture & 6 & 1.05 & 4.72 \\
Organizational Identification & 6 & 1.05 & 4.72 \\
Organizing & 6 & 1.05 & 4.72 \\
Communication Constitutes Organizations (CCO) & 5 & 0.88 & 3.94 \\
Culture(s) & 5 & 0.88 & 3.94 \\
Discourse & 5 & 0.88 & 3.94 \\
Emotion & 5 & 0.88 & 3.94 \\
Mixed Methods & 5 & 0.88 & 3.94 \\
Nonprofit(s) & 5 & 0.88 & 3.94 \\
Organization & 5 & 0.88 & 3.94 \\
Socialization & 5 & 0.88 & 3.94 \\
\hline
\end{tabular}

NOTE. - List represents $25.79 \%$ of all keywords $(N=570)$ used.

Review of Communication, Vol. 14, No. 2 (2014): pg. 89-106. DOI. This article is (C) Taylor \& Francis (Routledge) and permission has been granted for this version to appear in e-Publications@ Marquette. Taylor \& Francis (Routledge) does not grant permission for this article to be further copied/distributed or hosted elsewhere without the express permission from Taylor \& Francis (Routledge). 
NOT THE PUBLISHED VERSION; this is the author's final, peer-reviewed manuscript. The published version may be accessed by following the link in the citation at the bottom of the page.

TABLE 5 PROPERTIES OF RESEARCH COLLABORATION NETWORK EXEMPLAR

\begin{tabular}{|c|c|c|c|c|}
\hline SCHOLAR & DISTANCE & DEGREE & $\begin{array}{c}\text { BONACICH'S } \\
\text { POWER }\end{array}$ & $\begin{array}{c}\text { BETWEENNESS } \\
\text { CENTRALITY }\end{array}$ \\
\hline Stanley Deetz & N/A & 7 & 1267.39 & 3840.10 \\
\hline Timothy Kuhn & 1 & 9 & 2268.63 & 6976.33 \\
\hline Sarah Tracy & 1 & 8 & 800.92 & 2789.50 \\
\hline Dennis Mumby & 1 & 5 & 1452.38 & 3802.39 \\
\hline Stacey Wieland & 1 & 2 & 301.17 & 244.02 \\
\hline Jeanne McPhearson & 1 & 2 & 289.43 & 248.00 \\
\hline Elizabeth Egar & 1 & 2 & 448.69 & 0.00 \\
\hline John McClellan & 1 & 1 & 274.72 & 0.00 \\
\hline Linda L. Putnam & 2 & 11 & 3202.41 & 12246.39 \\
\hline Marshall Scott Poole & 2 & 8 & 2130.48 & 7282.97 \\
\hline François Cooren & 2 & 7 & 1605.43 & 1560.41 \\
\hline Cynthia Stohl & 2 & 6 & 1391.42 & 5790.23 \\
\hline Sarah Riforgiate & 2 & 6 & 392.18 & 1604.44 \\
\hline Brenda Berkelaar & 2 & 5 & 1538.20 & 4103.94 \\
\hline Michele Horner Jackson & 2 & 5 & 1183.20 & 2293.93 \\
\hline Matthew Koschmann & 2 & 4 & 774.67 & 970.97 \\
\hline Steven Corman & 2 & 3 & 731.58 & 4096.08 \\
\hline Karen Lee Ashcraft & 2 & 2 & 622.19 & 52.18 \\
\hline Dennis Schoeneborn & 2 & 5 & 609.54 & 986.00 \\
\hline Angela Trethwey & 2 & 5 & 603.03 & 1624.63 \\
\hline Jennifer Mease & 2 & 5 & 447.75 & 1238.45 \\
\hline Pamela E. Lutgen-Sandvik & 2 & 5 & 417.65 & 878.03 \\
\hline Robin Clair & 2 & 5 & 392.83 & 986.00 \\
\hline Jennifer Scarduzio & 2 & 3 & 194.56 & 495.00 \\
\hline Daniel Lair & 2 & 2 & 117.84 & 99.77 \\
\hline Kendra Rivera & 2 & 1 & 173.98 & 0.00 \\
\hline Shawna Malvini-Redden & 2 & 1 & 173.98 & 0.00 \\
\hline Eun Jong Han & 2 & 1 & 63.51 & 0.00 \\
\hline George Cheney & 3 & 9 & 780.42 & 4774.93 \\
\hline Kathleen Krone & 3 & 8 & 1408.73 & 6139.27 \\
\hline Laurie Lewis & 3 & 7 & 714.27 & 2093.60 \\
\hline Patrice Buzzanell & 3 & 7 & 694.44 & 2318.24 \\
\hline James R. Taylor & 3 & 6 & 1030.47 & 475.37 \\
\hline Craig R. Scott & 3 & 6 & 501.86 & 6753.20 \\
\hline Karen K. Myers & 3 & 5 & 1232.19 & 583.09 \\
\hline Paul Leonardi & 3 & 5 & 543.22 & 2489.94 \\
\hline
\end{tabular}

Review of Communication, Vol. 14, No. 2 (2014): pg. 89-106. DOI. This article is (C) Taylor \& Francis (Routledge) and permission has been granted for this version to appear in e-Publications@Marquette. Taylor \& Francis (Routledge) does not grant permission for this article to be further copied/distributed or hosted elsewhere without the express permission from Taylor \& Francis (Routledge). 
NOT THE PUBLISHED VERSION; this is the author's final, peer-reviewed manuscript. The published version may be accessed by following the link in the citation at the bottom of the page.

Table 5 continued

\begin{tabular}{|c|c|c|c|c|}
\hline Kasey L. Walker & 3 & 5 & 376.64 & 986.00 \\
\hline Justin Boren & 3 & 5 & 111.34 & 986.00 \\
\hline Boris H. J. M. Brummans & 3 & 4 & 1327.01 & 749.18 \\
\hline Jody Jahn & 3 & 4 & 1271.60 & 588.19 \\
\hline Gail T. Fairhurst & 3 & 4 & 1204.92 & 971.00 \\
\hline Jaime Bochantin & 3 & 4 & 822.31 & 2416.15 \\
\hline Noshir Contractor & 3 & 4 & 707.53 & 2602.07 \\
\hline David Seibold & 3 & 3 & 892.00 & 1475.55 \\
\hline Jo Katambwe Mulamba & 3 & 3 & 651.14 & 69.50 \\
\hline Johny T. Garner & 3 & 3 & 608.42 & 2072.13 \\
\hline Beverly Sypher-Davenport & 3 & 3 & 449.47 & 1657.86 \\
\hline Brittany Peterson & 3 & 3 & 261.99 & 689.28 \\
\hline Brenden Kendall & 3 & 3 & 235.19 & 157.40 \\
\hline Patricia Parker & 3 & 3 & 225.43 & 370.15 \\
\hline Rebecca Gill & 3 & 3 & 176.83 & 337.72 \\
\hline Frederic M. Jablin & 3 & 2 & 997.87 & 0.00 \\
\hline Daniel Robichaud & 3 & 2 & 571.28 & 0.00 \\
\hline Robert D. McPhee & 3 & 2 & 504.37 & 465.15 \\
\hline Lorraine Kisselburgh & 3 & 2 & 484.18 & 0.00 \\
\hline Cliff Scott & 3 & 2 & 398.35 & 184.71 \\
\hline Matthew Isbell & 3 & 2 & 323.57 & 0.00 \\
\hline Bud Goodall & 3 & 2 & 216.00 & 613.31 \\
\hline Heather Canary & 3 & 2 & 195.63 & 287.23 \\
\hline Jess Alberts & 3 & 2 & 176.90 & 0.00 \\
\hline Geraldine DeSanctis & 3 & 1 & 461.12 & 0.00 \\
\hline Gino Giannini & 3 & 1 & 430.02 & 0.00 \\
\hline Nicholas Bencherki & 3 & 1 & 347.72 & 0.00 \\
\hline Michael Stohl & 3 & 1 & 301.50 & 0.00 \\
\hline Sandi W. Smith & 3 & 1 & 301.50 & 0.00 \\
\hline Nan $\mathrm{Li}$ & 3 & 1 & 256.54 & 0.00 \\
\hline Renee Houston Henning & 3 & 1 & 256.54 & 0.00 \\
\hline Stefan Wehmeier & 3 & 1 & 132.64 & 0.00 \\
\hline Consuelo Vasquez & 3 & 1 & 132.64 & 0.00 \\
\hline Steffen Blashke & 3 & 1 & 132.64 & 0.00 \\
\hline Swaran Sandhu & 3 & 1 & 132.64 & 0.00 \\
\hline Brittany Collins & 3 & 1 & 97.70 & 0.00 \\
\hline David Terry & 3 & 1 & 97.70 & 0.00 \\
\hline Virgina McDermott & 3 & 1 & 91.20 & 0.00 \\
\hline Canchu Lin & 3 & 1 & 85.84 & 0.00 \\
\hline Amardo Rodriguez & 3 & 1 & 85.84 & 0.00 \\
\hline Rebekah Fox & 3 & 1 & 85.84 & 0.00 \\
\hline Marifran Mattson & 3 & 1 & 85.84 & 0.00 \\
\hline Yvonne Montoya & 3 & 1 & 85.70 & 0.00 \\
\hline Patricia Geist-Marin & 3 & 1 & 43.02 & 0.00 \\
\hline
\end{tabular}

NOTE. - Example Network: $\mathrm{N}=80$, Possible Connections $=3160$, Existing

Connections $=105$, Network Density $=3.32 \%$

Review of Communication, Vol. 14, No. 2 (2014): pg. 89-106. DOI. This article is (C) Taylor \& Francis (Routledge) and permission has been granted for this version to appear in e-Publications@Marquette. Taylor \& Francis (Routledge) does not grant permission for this article to be further copied/distributed or hosted elsewhere without the express permission from Taylor \& Francis (Routledge). 
NOT THE PUBLISHED VERSION; this is the author's final, peer-reviewed manuscript. The published version may be accessed by following the link in the citation at the bottom of the page.

\section{Notes:}

${ }^{1}$ See, for example, Patrice Buzzanell and Cynthia Stohl, "The Redding Tradition of Organizational Communication Scholarship: W. Charles Redding and His Legacy," Communication Studies 50 (1999): 324-336.

2 See, for example, Gail T. Fairhurst, Discursive Leadership: In Conversation with Leadership Psychology (Los Angeles: Sage, 2007); Gail T. Fairhurst and Linda L. Putnam, "Organizations as Discursive Constructions," Communication Theory 14 (2004): 5-26.

${ }^{3}$ Linda L. Putnam and Anne Nicotera, Building Theories of Organization: The Constitutive Role of Communication (New York: Routledge, 2009).

${ }^{4}$ Karen Lee Ashcraft, Timothy R. Kuhn, and Francois Cooren, "Constitutional Amendments: 'Materializing' Organizational Communication," The Academy of Management Annals 3 (2009): 1-64; Bruno Latour, Reassembling the Social: An Introduction to Actor-Network Theory (Oxford: Oxford University Press, 2007).

${ }^{5}$ See, for example, Ashcraft, Kuhn, and Cooren, "Constitutional Amendments", 1-64; Sarah B. Feldner and Scott C. D'Urso, "Threads of Intersection and Distinction: Joining an Ongoing Conversation within Organizational Communication Research," Communication Research Trends 29 (2010): 3-28; Dennis K. Mumby and Cynthia Stohl, "Disciplining Organizational Communication Studies," Management Communication Quarterly 10 (1996): 50-72; David Rooney, Bernard McKenna, and James R. Barker, "History of Ideas in Management Communication Quarterly," Management Communication Quarterly 25 (2011): 583-611; James R. Taylor, Andrew J. Flanagin, G. Cheney, and David R. Seibold, "Organizational Communication Research: Key Moments, Central Concerns, and Future Challenges," in Communication Yearbook, ed. W. B. Gudykunst (Thousand Oaks, CA: Sage, 2001), 99-137.

${ }^{6}$ Patrice M. Buzzanell, Jeremy P. Fyke, and Robyn V. Remke. 2014. "Professionalising Organizational Communication Discourses, Materialities, and Trends. In The Routledge Handbook of Language and Professional Communication, ed. V. Bhatia and S. Bremner (New York: Routledge), 207-219.

7 Dennis K. Mumby, and Linda L. Putnam, eds. 2014. The Sage Handbook of Organizational Communication (3rd ed.). Thousand Oaks: Sage.

${ }^{8}$ Charles W. Redding, "Stumbling Toward Identity: The Emergence of Organizational Communication as a Field of Study," in Organizational Communication: Traditional Themes and New Directions, ed. R.D. McPhee and P.K. Tompkins (Beverly Hills, CA: Sage, 1985), 15-54.

Review of Communication, Vol. 14, No. 2 (2014): pg. 89-106. DOI. This article is (C) Taylor \& Francis (Routledge) and permission has been granted for this version to appear in e-Publications@Marquette. Taylor \& Francis (Routledge) does not grant permission for this article to be further copied/distributed or hosted elsewhere without the express permission from Taylor \& Francis (Routledge). 
${ }^{9}$ See, for example, Francisco J. Acedo et al., "Co-Authorship in Management and Organizational Studies: An Empirical and Network Analysis," Journal of Management Studies 43 (2006): 957-983.

10 Katherine I. Miller, "A Stroll Down Memory Lane (In Flip Flops)," Management Communication Quarterly 18 (2005): 612-617.

${ }^{11}$ Peter R. Monge and Noshir S. Contractor, Theories of Communication Networks, (New York: Oxford University Press, 2003).

12 See, for review, Alex M. Susskind, Donald F. Schwartz, William D. Richards, and David Johnson, "Evolution and Diffusion of the Michigan State University Research Tradition of Organizational Communication Network Research," Communication Studies 54 (2005): 397-418.

${ }^{13}$ Ingrid Ticken-Boon van Ostade, "Social Network Analysis and the History of English," European Journal of English Studies 4 (2000): 211-216.

${ }^{14}$ Peter M. Kristensen, "Dividing Discipline: Structures of Communication in International Relations," International Studies Review 14 (2012): 3250.

${ }^{15}$ Hans Baumgartner and Rik Pieters, "The Structural Influence of Marketing Journals: A Citation Analysis of the Discipline and Its Subareas Over Time," Journal of Marketing 67 (2003): 123-139.

16 Acedo et al, "Co-Authorship in Management and Organization Studies," 957-983.

17 Ibid.

18 Kristensen, "Dividing Discipline," 32-50.

${ }^{19}$ Adapted from Monge and Contractor, "Theories of Communication Networks."; Hanneman, Robert A. \& Mark Riddle. 2005. Introduction to Social Network Method. Riverside, CA: University of California, Riverside; Prell, Christina. 2012. Social Network Analysis: History, Theory, and Methodology. London: Sage.

${ }^{20}$ Borgatti, Stephen P., Everett, Martin G. and Linton C. Freeman. 2002. Ucinet 6 for Windows: Software for Social Network Analysis. Harvard, MA: Analytic Technologies.

${ }^{21}$ Borgatti, Stephen P., 2002. NetDraw Software for Network Visualization. Analytic Technologies: Lexington, KY.

22 Miller, "Stroll Down Memory Lane," 616.

${ }^{23}$ R. Dean Malmgren, Julio M. Ottino, and Luis A. Nunes Amaral, "The Role of Mentorship in Protégé Performance," Nature 465 (2010): 622-626.

Review of Communication, Vol. 14, No. 2 (2014): pg. 89-106. DOI. This article is (C) Taylor \& Francis (Routledge) and permission has been granted for this version to appear in e-Publications@ Marquette. Taylor \& Francis (Routledge) does not grant permission for this article to be further copied/distributed or hosted elsewhere without the express permission from Taylor \& Francis (Routledge). 
24 Michael J. Piette and Kevin L. Ross, "A Study of the Publication of Scholarly Output in Economics Journals," Eastern Economic Journal 18 (1992): 429-436.

25 Acedo et al., "Co-Authorship in Management and Organization Studies," 957-983.

Lidwien van de Wijngaert, Harry Bouwman, and Noshir Contractor, "A Network Approach Toward Literature Review," Quality \& Quantity 48 (2014): 623-643.

27 Kristensen, "Dividing Discipline," 32-50.

28 David N. Laband and Robert D. Tollison, "Intellectual Collaboration," Journal of Political Economy 108 (2000): 632-662.

${ }^{29}$ Acedo et al, "Co-Authorship in Management and Organization Studies," 957-983.

30 David N. Laband, "Publishing Favoritism: A Critique of Department Ratings Based on Quantitative Publishing Performance," Southern Economic Journal 52 (1985): 510-515.

31 Piette and Ross, "A Study of Publication of Scholarship Output," 429-436.

32 The survey only asked for the top five most frequent co-authors. Current data collection of recent CVs allows us to record more co-authors for each scholar. Ultimately, this affords a more complete network, which is important methodologically. Take, for example, Cynthia Stohl. She has co-authored with 58 individuals as of March 2013. Her top five most frequent does not include Kasey Walker, twice a Stohl publication co-author, but Walker's list includes Stohl. This process allows for more than five network connections for any one individual, and in the case of Stohl, it results in an additional 52 connections.

33 Prell, Social Network Analysis.

34 Acedo et al, "Co-Authorship in Management and Organization Studies," 957-983.

${ }^{35}$ Kevin J. Barge, "Practical Theory as Mapping, Engaged Reflection, and Transformative Practice," Communication Theory 11 (2001): 5-13.

${ }^{36}$ Elizabeth Jones, Burnadette Watson, John Gardner, and Cindy Gallois, "Organizational Communication: Challenges for the New Century," Journal of Communication 54 (2004): 722- 750.

37 Craig R. Scott, Anonymous Agencies, Backstreet Businesses and Covert Collectives: Rethinking Organizations in the 21st Century (Stanford, CA: Stanford Business Books).

Review of Communication, Vol. 14, No. 2 (2014): pg. 89-106. DOI. This article is (C) Taylor \& Francis (Routledge) and permission has been granted for this version to appear in e-Publications@Marquette. Taylor \& Francis (Routledge) does not grant permission for this article to be further copied/distributed or hosted elsewhere without the express permission from Taylor \& Francis (Routledge). 
NOT THE PUBLISHED VERSION; this is the author's final, peer-reviewed manuscript. The published version may be accessed by following the link in the citation at the bottom of the page.

${ }^{38}$ Redding, "Stumbling Toward Identity," 15-54.

${ }^{39}$ Feldner and D’Urso, "Threads of Intersection and Distinction," 3-28.

${ }^{40}$ We thank one anonymous reviewer for this specific suggestion.

Review of Communication, Vol. 14, No. 2 (2014): pg. 89-106. DOI. This article is (C) Taylor \& Francis (Routledge) and permission has been granted for this version to appear in e-Publications@Marquette. Taylor \& Francis (Routledge) does not grant permission for this article to be further copied/distributed or hosted elsewhere without the express permission from Taylor \& Francis (Routledge). 